\title{
What Drives Japanese Whaling Policy?
}

\author{
Christopher Butler-Stroud * \\ Whale and Dolphin Conservation, Chippenham, UK
}

Keywords: whaling, Japan, fisheries, science, politics

\section{WHAT DRIVES JAPANESE WHALING POLICY?}

The debates about whaling are reported to hinge around the issues of animal welfare (Brakes and Simmonds, 2011), science (Burnett, 2012) and clashes over differing cultural perspectives (Hirata, 2005). However, the dynamics that shape the hunting of the great whales managed through the International Whaling Commission (IWC), are much more complex. Stakeholders act under significant forces not always directly relevant to the conservation or exploitation of wildlife, or indeed, the marginal profits available from whaling. It is argued that it is domestic Japanese politics (Clapham et al., 2007) and attempts to create new norms in more economically important fisheries agreements that now drive the demand for continued whaling.

Japan is one of the few states in the world that assertively supports its claims to resume commercial whaling. The IWC enacted a moratorium on commercial whaling in 1982 but even before the zero catch quotas had come into force the Japanese Minister of Agriculture, Forestry and Fisheries, Moriyoshi Sato, stated,

\section{OPEN ACCESS}

Edited by:

Andrew Butterworth,

University of Bristol, UK

Reviewed by:

Mark Peter Simmonds,

Humane Society International, UK

*Correspondence:

Christopher Butler-Stroud chris.butler-stroud@whales.org

Specialty section:

This article was submitted to

Marine Affairs and Policy,

a section of the journal

Frontiers in Marine Science

Received: 18 March 2016

Accepted: 06 June 2016

Published: 22 June 2016

Citation:

Butler-Stroud C (2016) What Drives

Japanese Whaling Policy?

Front. Mar. Sci. 3:102.

doi: 10.3389/fmars.2016.00102
"The government will do its utmost to find out ways to maintain the nation's whaling in the form of research or other forms" (Cherfas, 1985).

Thus, began a sustained programme of "resistance" to the implementation of the IWC moratorium. This included launching a programme of "scientific" permit whaling, ostensibly allowed for under Article VIII of the International Convention for the Regulation of Whaling (ICRW). Indeed, Japan's extensive Antarctic whaling only paused when it was ruled illegal and "not for the purposes of science" by the International Court of Justice (ICJ) in its landmark 2014 ruling $^{1}$ However, in late 2015, despite failing to obtain IWC or scientific support, Japan's whaling fleet sailed to the Antarctic under a new permit (NEWREP-A) ${ }^{2}$ with the intention of taking 333 minke whales. At the same time Japan signaled that it would not countenance any future challenges when it withdrew from the jurisdiction of the ICJ with respect to "research on, or conservation, management or exploitation of, living resources of the sea" 3

But maybe this assertive move should not have come as a shock to observers of Japanese policy within the IWC.

The 1946 signing of the ICRW was an important jurisprudential step in establishing the principle of international regulation of a common property resource both in the high seas and national waters. However, since joining the IWC in 1951, Japan has actively sought to limit IWC jurisdiction, for example, increasingly asserting its sovereignty within its 200 mile Exclusive Economic Zone

\footnotetext{
${ }^{1}$ Whaling in the Antarctic (Australia vs. Japan: New Zealand intervening) Judgment of 31 March 2014: http://www.icj-cij.org/docket/index.php?p1 $=3 \& \mathrm{p} 2=1 \&$ case $=148 \& \mathrm{pp} 3=4$.

${ }^{2}$ Government of Japan, NEWREP-A: Available online at: https://iwc.int/document_3550.

${ }^{3}$ Yoshikawa, M., Permanent Representative of Japan to the United Nations (6th October, 2015) International Court of Justice: Available online at: http://www.icj-cij.org/jurisdiction/?p1 $=5 \& \mathrm{p} 2=1 \& \mathrm{p} 3=3 \& \operatorname{code}=J \mathrm{P}$.
} 
(EEZ) over the accepted norms of IWC control of whaling in "all waters in which whaling is prosecuted"4 and subsequently arguing against IWC competency for small cetaceans (Morikawa, 2009).

The use of IWC objections procedures and the creative interpretation of Article VIII permits, appears to be a strategy to bring the IWC to an impasse, allowing Japan to claim that the IWC is "dysfunctional" (Kirby, 2006). Alongside procedural maneuvers Japan has encouraged social scientists to champion views that exemptions for Inuit whalers under Aboriginal Subsistence Whaling (ASW) should lead to a broader definition of "subsistence" that allows for a greater amount of commercial trade (Schieber, 1998) - a result that could directly benefit its coastal whaling operations for which Japan has consistently claimed similarities to ASW.

The recent decision by Japan to apparently disregard the IWC's scientific committee's critiques (Brierley and Clapham, 2016), and to withdraw from the jurisdiction of the ICJ appears to increasingly indicate that Japan's powerful Ministry of Fisheries seeks not be bound by international norms with respect to whaling and should be a warning bell for any nations engaged in any resource access debate with Japan. Indeed Clapham (2015) believes that the history of Japan in the IWC in "deny[ing] the existence of population declines and the need for lower catch limits, exploitation of IWC procedures to block or delay progressive measures..." has been a fundamental way of working for Japan since it joined.

Some authors have pointed to the incestuous relationships between the Japanese Government and those who profit from whaling. For example, Clapham (2015) notes the Institute of Cetacean Research (ICR), the "quasi-governmental" body that carries out "scientific" whaling, is funded by sales of whale meat and from direct subsidies, whilst the government relies on the "independence" of the ICR to claim scientific legitimacy of its continued use of an IWC loophole. Atsushi and Okubo (2007) go so far as to argue that this relationship is so institutionalized that Japan has been happy with the scientific whaling status quo.

Morikawa (2009) points to the policy of aging whaling proponents amongst the Ministry of Fisheries "retiring" into the fisheries conglomerates that financially benefit from Japan's continued whaling. Hirata (2005) argues that this domestic bubble of shared interests makes Japan almost impervious to external pressures when it comes to ending whaling.

Furthermore, some commentators remain cautious about Japan changing its position anytime soon. Clapham (2015) notes that Japan is intent on "pursuing its long-term plan of attempting to obtain the votes necessary to lift the moratorium and reinstate commercial whaling."

Japan had announced as early as 1999 that it was giving aid to countries in the hope of changing the balance of votes at the Commission (Brown, 1999). The then Japanese Vice-Minister for Fisheries stated:

\footnotetext{
"We would like to utilise overseas development aid as a practical means to promote nations to join... which support Japan's claim"
}

$\overline{{ }^{4} \text { ICRW (1946) Article 1(2): https://archive.iwc.int/pages/view.php? } r e f=3607 \& k=.}$
Like many nations, Japan had, post 1960, established a programme of using overseas development aid (ODA) to build its international reputation. In contrast to its behavior in the IWC, the Japanese ODA Blue Book calls for the "establishment of the 'rule of law' in the international community" (Japanese Diplomatic Blue Book, 2013). However, a 2012 review of Japanese $\mathrm{ODA}^{5}$ states that "it is necessary to grasp not only the development effect but also the diplomatic effect," of such aid,

\footnotetext{
"Developing mutual understanding concerning sustainable use of resources, without undue emphasis on conservation...' and, 'Supporting Japan's position on issues such as the use of marine resources, etc. in the international arena..."
}

The withdraw of Japan from the jurisdiction of the ICJ and its preference for any future adjudication under other provisions of the United Nations Convention on the Law of the Sea (UNCLOS) may evidence an underlying strategy of increasingly militating against the effects of multilateral governance regimes when it inconveniences them.

But this is not a new strategy. In the 1970s Japan had fought against the creation of EEZs under the United Nations Convention on the Law of the Sea (UNCLOS). As Tarte (1998) notes,

“...Shock waves spread quickly through the Japanese fishing industry... Fishing access agreements became a necessity within Pacific nations' territorial waters, and it is in this context, that the catalyst for Japanese foreign aid to the region can be found".

According to Tarte, the precedence of Japanese interests over the preferences of the recipients has remained a constant feature of Japan's aid programme to the region. Within these programmes Cosgriff (2001) notes, "By keeping negotiations bilateral, Japan is able to exploit divisions between states to maximise its bargaining power."

Thus, where possible, Japan has sought to maximize its fisheries opportunities outside of multilateral agreements. Its withdrawal from the jurisdiction of the ICJ should be viewed with some concern as it potentially significantly limits any future challenge to Japan's scientific whaling in an international court, or, indeed, with respect to any fisheries issues. Amor (2012) notes that the ICJ and the Law of the Sea Tribunal (ITLOS) "are serving a common goal of a mutually reinforcing corpus of international law" but also notes that the ITLOS has regularly referred to the judgments of the Court "with respect to questions of international law and procedure," and also that the Court enjoys a more "general and comprehensive jurisdiction than specialized judicial bodies." Becker (2015) develops this thought, noting that in seeking arbitration through UNCLOS any "claims to be litigated would need to concern the interpretation or application of a UNCLOS provision" and could not address the generality of Japan's actions with respect to the ICRW.

\footnotetext{
${ }^{5}$ Nomura Research Institute, Ltd. (2012) Evaluation of Grant Aid for Fisheries: http://www.mofa.go.jp/policy/oda/evaluation/FY2011/text-pdf/fisheries.pdf.
} 
The domestic power of the whaling block within the Japanese Ministry of Fisheries should not be underestimated. Work by Strand and Truman (2009) suggests that the Fisheries Ministry has been the main beneficiary of an aggressive ODA policy, within the context of the Japanese Government solidifying its rhetoric around a distinctly nationalistic agenda.

Of growing concern to many external observers ${ }^{6}$ is the rise of Nippon Kaigi, a nationalistic revisionist grouping within the Japanese Cabinet, Diet and Japanese society (Day, 2014). Historical issues have long colored Japan's relationships with its neighbors, particularly China and South Korea, but this new nationalism is seeking to redefine and reinforce whaling as part of the nationalist narrative. This nationalistic linkage to whaling goes back to at least 1982. The Liberal Democratic Party (LDP), then, as now, wishing to shore up its rural political support, including from fishing communities (Moreby, 1982), has been careful to back the establishment's whaling position. There is even an LDP Parliamentary League for Whaling.

This author suggests that the nationalistic rhetoric and accompanying spurious projection of Japan's problems as being caused by Euro-American aggression (Oh and Ishizawa-Grbić, 2000) helps us understand the way whaling is used as a symbol of "being Japanese" and of a Japan that is perceived to be under constant external pressure by foreigners.

\footnotetext{
${ }^{6}$ Congressional Research Service (2014) 'Japan-U.S. Relations: Issues for Congress (page 6), 24 February. Available online at: http://mansfieldfdn.org/mfdn2011/wpcontent/uploads/2014/02/USJ.Feb14.RL33436.pdf.
}

\section{REFERENCES}

Amor, B. S. (2012). "The International Court of Justice and the Law of the Sea," in Universidad Nacional Autónoma de MéxicoInstituto de Investigaciones Jurídicas. Mexico: Anuario Mexicanode Derecho Internacional, Décimo Aniversario, 2-26. Available online at: http://www.corteidh.or.cr/tablas/r29686.pdf

Atsushi, I., and Okubo, A. (2007). An alternative explanation of Japan's Whaling Diplomacy in the Post-Moratorium Era. J. Int. Wildlife Law Policy 10, 55-87. doi: 10.1080/13880290701229911

Becker, M. J. (2015). Japan's New Optional Clause Declaration at the ICJ: A PreEmptive Strike? Blog of the European Journal of International Law. Available online at: http://www.ejiltalk.org/japans-new-optional-clause-declaration-atthe-icj-a-pre-emptive-strike/

Brakes, P., and Simmonds, M. P. (2011). Whales and Dolphins, Cognition, Culture, Conservation and Human Perceptions. London: Earthscan.

Brierley, A. S., and Clapham, P. J. (2016). Whaling permits: Japan's whaling is unscientific. Nature 529, 283. doi:10.1038/529283a

Brown, P. (1999). Japan Admits Using Aid to Build Pro-Whaling Vote. London: Guardian Newspaper. Available online at: http://www.theguardian. com/environment/1999/nov/11/whaling.internationalnews

Burnett, D. G. (2012). The Sounding of the Whale, Science and Cetaceans in the Twentieth Century. Chicago, IL: The University of Chicago Press.

Cherfas, J. (1985). More whales harpooned 'for science.' New Scientist 105:1044.
It also allows us to contextualize the Japanese nationalist polemic that whaling is a Japanese "tradition" that has been subject to foreign attempts to control the "very soul of Japan." As noted by O'Dwyer (2013), "While most Japanese today rarely eat whale meat, some defend pelagic whaling out of a belief that Japanese eating habitats should not be dictated to by foreign activists"

Thus, it is argued here that Japanese whaling policy is a complex product of domestic political forces, an industry maintained by direct and indirect subsidies, and an increasing nationalistic whaling narrative. Maybe more worryingly, we should recognize that the debate within the IWC is not just about protecting whales, but is increasingly a testing ground for Japan in establishing new international norms for the exploitation of all marine species, and that the consequences of acquiescence to Japan's ambitions will have major repercussions for many other species in desperate need of international conservation.

\section{AUTHOR CONTRIBUTIONS}

The author confirms being the sole contributor of this work and approved it for publication.

\section{ACKNOWLEDGMENTS}

My thanks to Nicola Hodgins, Vanesa Tossenberger, Vicki James, Jane Bryan, and Astrid Fuchs for reviewing early drafts.

Clapham, P. J. (2015). Japan's whaling following the International Court of Justice ruling: brave New World - Or business as usual? Mar. Policy 51, 238-241. doi: 10.1016/j.marpol.2014.08.011

Clapham, P. J., Childerhouse, S., Gales, N. J., Rojas-Brancho, L., Tillman, M. F., and Brownell, R. L. (2007). The whaling issue: conservation, confusion, and casuistry. Mar. Policy 31, 314-319. doi: 10.1016/j.marpol.2006. 09.004

Cosgriff, B. (2001). ODA: Official Development Assistance or Opportunity, Duty and Agenda? A Comparative Analysis Of Japan And Australia As Foreign Aid Donors In The South Pacific 1976-2000. MA Thesis. Canterbury: Univeristy of Canturbury.

Day, J. (2014). Blog: abe unifies far-right ideology in upper echelons of Japanese politics. China News Agency. Available online at: http://news.xinhuanet.com/ english/world/2014-09/08/c_133628335.htm

Hirata, K. (2005). Why Japan supports whaling. J. Int. Wildlife Law Policy 8, 129-149. doi: 10.1080/13880290590 965276

Japanese Diplomatic Blue Book (2013). Japan's Foreign Policy in Major Diplomatic Fields. 25-26. Available online at: http://www.mofa.go.jp/files/000019042.pdf

Kirby, A. (2006). Japan sets 2006 whaling ultimatum. BBC News. Available online at: http://news.bbc.co.uk/1/hi/sci/tech/3907415.stm

Moreby, C. (1982). What whaling means to the Japanese. New Scientist 31, 661-663.

Morikawa, J. (2009). Whaling in Japan, Power, Politics and Diplomacy. London: Hurst and Company. 
O’Dwyer, S. (2013). A Japanese poet's whale elegy. The Japan Times. Available online at: http://www.japantimes.co.jp/opinion/2013/04/10/commentary/ japan-commentary/a-japanese-poets-whale- elegy/\#.VxirTJMrJE5

Oh, I., and Ishizawa-Grbić, D. (2000). Forgiving the culprits: Japanese historicalrevisionism in a post-cold war context. Int. J. Peace Stud. - 5:2.http:// www.gmu.edu/programs/icar/ijps/vol5_2/oh_grbi.html

Schieber, H. N. (1998). Historical Memory, cultural claims, and environmental ethics in the jurisprudence of whaling regulation. Ocean Coast. Manag. $38,5-40$.

Strand, J., and Truman, J. (2009). Japanese Foreign Aid to Microstates and Voting in the International Whaling Commission: Evidence from Latin America and the Caribbean. Las Vegas: University of Nevada.
Tarte, S. (1998). Japan's Aid Diplomacy and the Pacific Islands. Canberra, ACT: Australian National University.

Conflict of Interest Statement: The author declares that the research was conducted in the absence of any commercial or financial relationships that could be construed as a potential conflict of interest.

Copyright (c) 2016 Butler-Stroud. This is an open-access article distributed under the terms of the Creative Commons Attribution License (CC BY). The use, distribution or reproduction in other forums is permitted, provided the original author(s) or licensor are credited and that the original publication in this journal is cited, in accordance with accepted academic practice. No use, distribution or reproduction is permitted which does not comply with these terms. 